\title{
АНАЛІЗ ПОВТОРНИХ ВИПАДКІВ ЗАХВОРЮВАННЯ В ОЦІНЦІ ВАРТОСТІ ЗАХВОРЮВАННЯ НА РОТАВІРУСНУ ІНФЕКЦІЮ
}

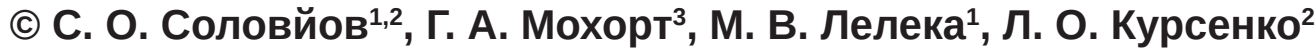

\author{
Національна медична академія післядипломної освіти імені П. Л. Шупика ${ }^{1}$ Київ \\ Національний технічний університет України «Київський політехнічний інститут \\ імені Ігоря Сікорського»², Київ \\ Національний медичний університет імені О. О. Богомольця, Київ \\ solovyov.nmape@gmail.com
}

\begin{abstract}
Мета роботи. Оцінка повторних випадків захворювання на ротавірусну інфрекцію (РВІ) 3 використанням ретроспективних епідеміологічних даних та методів математичного та комп'ютерного моделювання.

Матеріали і методи. Інорормаційним підґрунтям аналізу стали ретроспективні епідеміологічні дані щомісячної захворюваності на РВІ в Україні з 2010 до 2016 р., надані Центром Громадського здоров'я МОЗ України. Використано методи математичного та комп'ютерного моделювання в середовищі Visual Studio 2017.

Результати й обговорення. 3 використанням власного розробленого програмного забезпечення визначено ймовірність захворювання на РВІ для різних вікових груп та очікувану кількість первинного та наступних випадків захворювання для дітей перших п'яти років життя. Визначено, що найбільшою є ймовірність захворювання на РВІ у дітей віком від 1 до 2 років, що узгоджується із загальносвітовими тенденціями. Незважаючи на те, що у світі прийнято брати до уваги перші декілька випадків захворювання на РВІ, результати комп'ютерного моделювання показали, що кількість первинних випадків захворювання значно домінує над кількістю повторних випадків у структурі захворюваності на РВІ серед дітей віком до п'яти років в Україні.

Висновки. Результати комп'ютерного моделювання з використанням ретроспективних даних захворюваності на PBI показали, що при проведенні фрармакоекономічних досліджень специфрічної профрілактики РВІ серед дітей України має бути врахована вартість першого випадку захворювання та можуть бути знехтувані наступні випадки як набагато менш ймовірні.
\end{abstract}

Ключові слова: ротавірусна інфекція; повторне захворювання; комп'ютерне моделювання; вакцинопрофрілактика.

Вступ. Проблема глобального поширення гострих кишкових інфекцій (ГКІ) сьогодні залишається актуальною [1-4]. Вони посідають одне з провідних місць серед інфекційних захворювань, поступаючись за частотою лише грипу та гострим респіраторним вірусним захворюванням $[5,6]$. За даними Всесвітньої організації охорони здоров'я (ВОО3), у світі реєструється понад 1 млрд випадків ГКІ в рік [7]. Спектр збудників, які викликають ГКІ, різноманітний і включає патогенні [8] та умовно-патогенні бактерії [9], найпростіші, а також віруси.

Ряд досліджень показав, що саме віруси викликають від 25 до 60 \% випадків ГКІ [10, 11]. Серед них ротавірусам належить провідна роль у структурі дитячих вірусних кишкових захворювань $[12,13]$. Незважаючи на те, що кількість летальних випадків в останні роки значно знизилися, й з них більше $80 \%$ реєструється в країнах Азії та Асррики, ротавірусна інфрекція (PBI) завдає істотної шкоди здоров'ю населення всіх країн незалежно від рівня економічного розвитку, зумовлюючи прямі і непрямі економічні ви- трати, що оцінюються сотнями мільярдів доларів на рік [14].

Як більш ранні, так і подальші клініко-лабораторні спостереження за $\mathrm{PBI}$, проведені в різних країнах, показали важливість як першого, так і наступних (повторних) випадків захворювання серед дітей, що можуть бути спричинені різними генотипами ротавірусів. Крім того, було показано, що ризик виникнення тяжкої форми захворювання залишається навіть після кількох епізодів реінфекції $[15,16]$.

Повторні випадки захворювання на PBI, тісно пов'язані 3 виникненням постінорекційного синдрому, орерментопатії, дисбіотичних порушень, інтестинальної алергії тощо. Така особливість інорекції вказує на актуальність дослідження повторних випадків захворювання на РВІ, особливо з огляду на очікувану ефективність специфічної профілактики захворювання [17].

Отже, метою роботи стало визначення та оцінка повторних випадків захворювання на РВІ з використанням ретроспективних епідеміологічних даних та методів математичного та комп'ютерного моделювання.

ISSN 2312-0967. Фармацевтичний часопис. 2018. № 2 
Матеріали і методи. Інфрормаційним підґрунтям аналізу стали ретроспективні епідеміологічні дані щомісячної захворюваності на РВІ в Україні (фрорма 3) 32010 до 2016 рр. (рис. 1), які надано Центром Громадського здоров'я МОЗ України.

Моделювання епідемічного процесу РВІ здійснювалося в середовищі Visual Studio 2017. Побудова такої моделі грунтується на ряді епідеміологічних припущень [18]. 3 огляду на особливості морфології віріону та генетичного апарату ротавірусів, їх здатності до формування нових реасортантних штамів, а також характеру епідемічного процесу PBI, ми запропонували аналітичну модель динаміки розподілу хворих на PBI осіб із віком як простий марківський процес [18], що враховує повернення до стану сприйнятливості після перенесеної РВІ - здорового стану 3 можливістю наступних випадків інфекції та повторні випадки захворювання (рис. 2).

Така модель може бути записана за допомогою наступної системи рівнянь, адаптованої до наявних ретроспективних щомісячних епідеміологічних даних:

$$
\left\{\begin{array}{l}
s_{a+1}=\left(1-p_{1_{a}}\right) \cdot s_{a}+p_{2 a} \cdot i_{a} \\
i_{a+1}=p_{1_{a}} \cdot s_{a}+\left(1-p_{2 a}\right) \cdot i_{a}
\end{array}\right.
$$

де $s_{a}$ - частка сприйнятливих осіб серед всіх осіб віком $a$;

$i_{\text {a }}$ частка хворих на PBI осіб серед всіх осіб віком a;

$p_{1 a}$ - ймовірність того, що сприйнятливі особи віком а захворіють на PBI;

$p_{2 a}$ - ймовірність того, що хворі на РВІ особи віком а одужають.

Припускаючи, що тривалість захворювання на РВІ становить менше одного місяця, вважається, що за один місяць хвора особа одужає з ймовірністю $\mathrm{p}_{2 a}=1$, звідки можливо знайти значення $\mathrm{p}_{1 \mathrm{a}}$ для всіх вікових інтервалів [a, a+1], розв'язавши наступне рівняння:

$$
i_{a+1}=p_{1 a} \cdot s_{a}
$$

звідки ймовірність захворювання на РВІ на кожному часовому інтервалі визначалася з використанням спостережних даних захворюваності на PBI як:

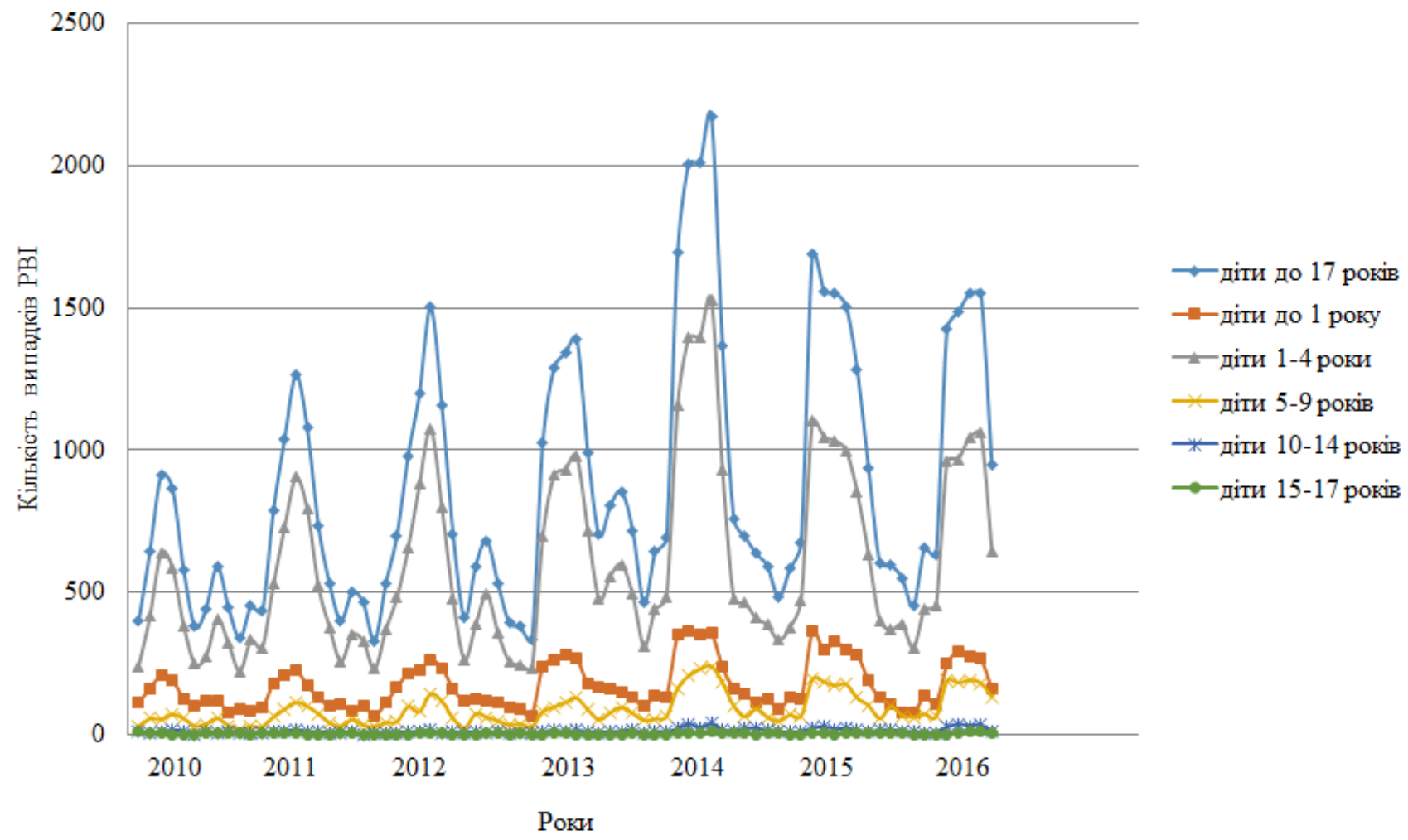

Рис. 1. Ретроспективні дані захворюваності на РВІ в Україні.

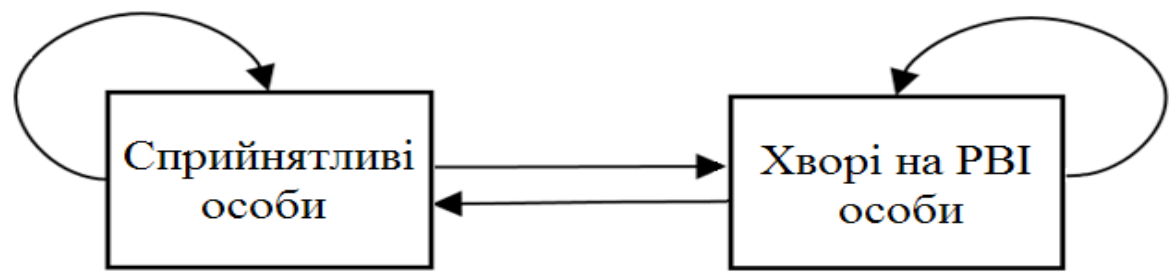

Рис. 2. Динаміка розподілу хворих на РВІ осіб із віком.

ISSN 2312-0967. Pharmaceutical review. 2018. № 2 


$$
p_{1 a}=\frac{i_{a+1}}{s_{a}}
$$

При знаходженні ймовірності захворювання на РВІ у віковій групі а було прийнято умову, що всі спостережні вікові групи уособлюють динаміку епідемічного процесу РВІ одних і тих самих осіб із віком.

Результати й обговорення. 3 використанням щомісячних даних спостережень за РВІ було визначено ймовірності захворювання на РВІ з урахуванням сезонних особливостей у різних вікових групах населення України в середовищі розробки Visual Studio 2017 (рис. 3).

Наступним кроком стало комп'ютерне моделювання захворюваності на РВІ для синтетичної популяції розміром 100 тисяч новонароджених осіб протягом перших п'яти років життя в середовищі розробки Visual Studio 2017 на основі розрахованих залежних від віку ймовірностей захворювання (рис. 3). Симуляція передбачала, що з народження і до п'ятирічного віку кожна дитина в синтетичній популяції мала визначену та залежну від віку ймовірність захворювання на РВІ, а отже, в кожному віковому інтервалі певна кількість осіб була хворою на РВІ. Паралельно підраховували кількість осіб, які були хворі на РВІ один або більше рази.
Результати комп'ютерного моделювання показали, що для 100 тисяч новонароджених осіб очікується близько 2 тисяч первинних випадків та 45 вторинних випадків захворювання на PBI протягом перших п'яти років життя (рис. 4). Такі результати вказують на те, що при оцінці есрективності вакцинопрофрілактики населення проти РВІ доцільно враховувати тільки первинний випадок захворювання, оскільки їх очікувана кількість $€$ набагато більшою, ніж наступних.

Висновки. В проведеному дослідженні було проаналізовано захворюваність на РВІ в різних вікових групах. Запропоновано математичну модель, яка відтворює вікові особливості епідемічного процесу РВІ серед дітей до 5 років в Україні. 3 використанням відповідного програмного забезпечення визначено ймовірність захворювання на РВІ для різних вікових груп та очікувану кількість первинного та наступних випадків для певної групи новонароджених осіб протягом п'яти років життя.

Результати дослідження показали, що найбільшою $€$ ймовірність захворювання на РВІ у дітей віком 1-2 роки, що узгоджується із загальносвітовими тенденціями. В той же час результати комп'ютерного моделювання показали відмінність у структурі повторних випадків захворювання. Незважаючи на те, що у світі прийнято брати до уваги перші декілька випадків за-

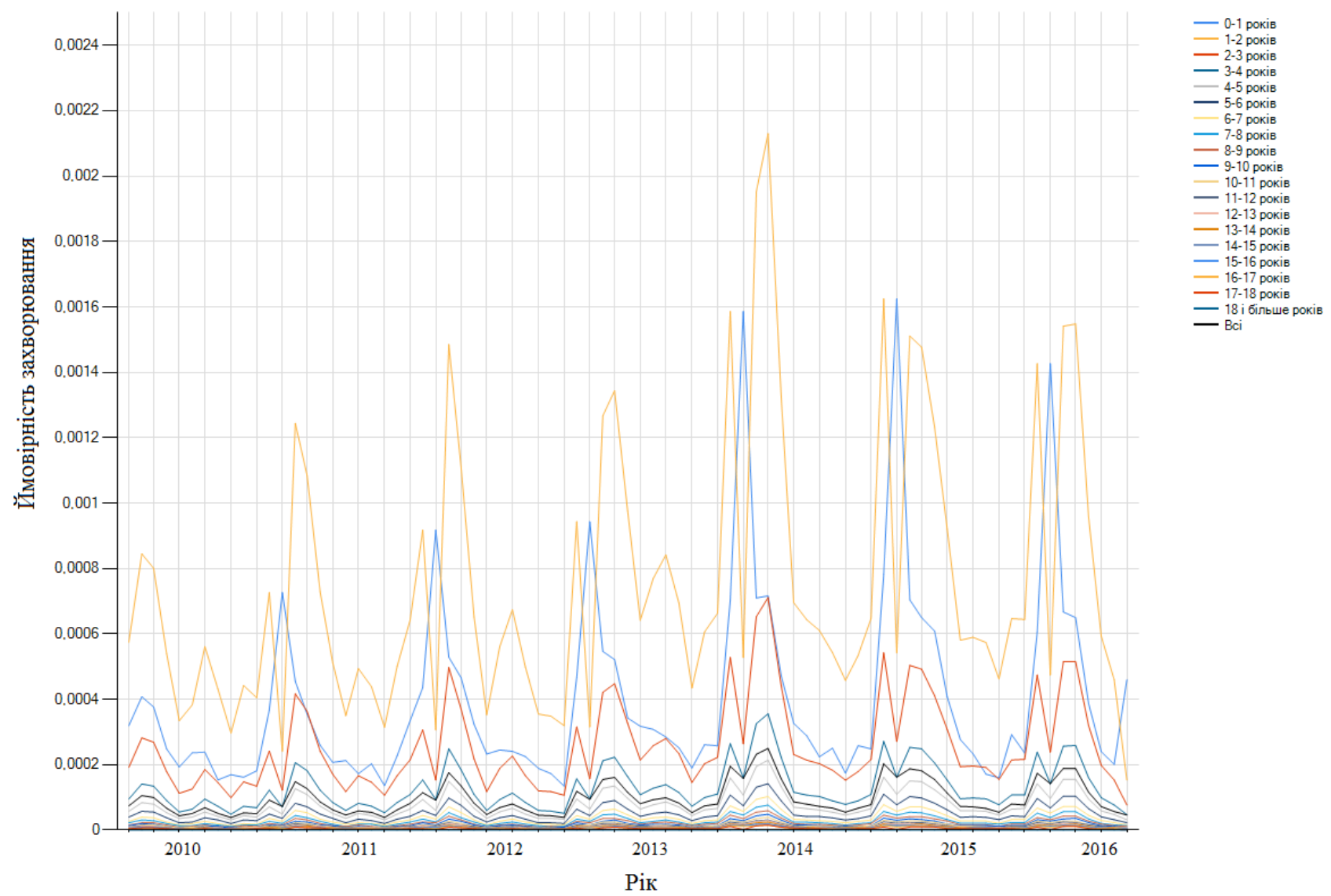

Рис. 3. Ймовірності захворювання на РВІ для осіб різного віку.

ISSN 2312-0967. Фармацевтичний часопис. 2018. № 2 


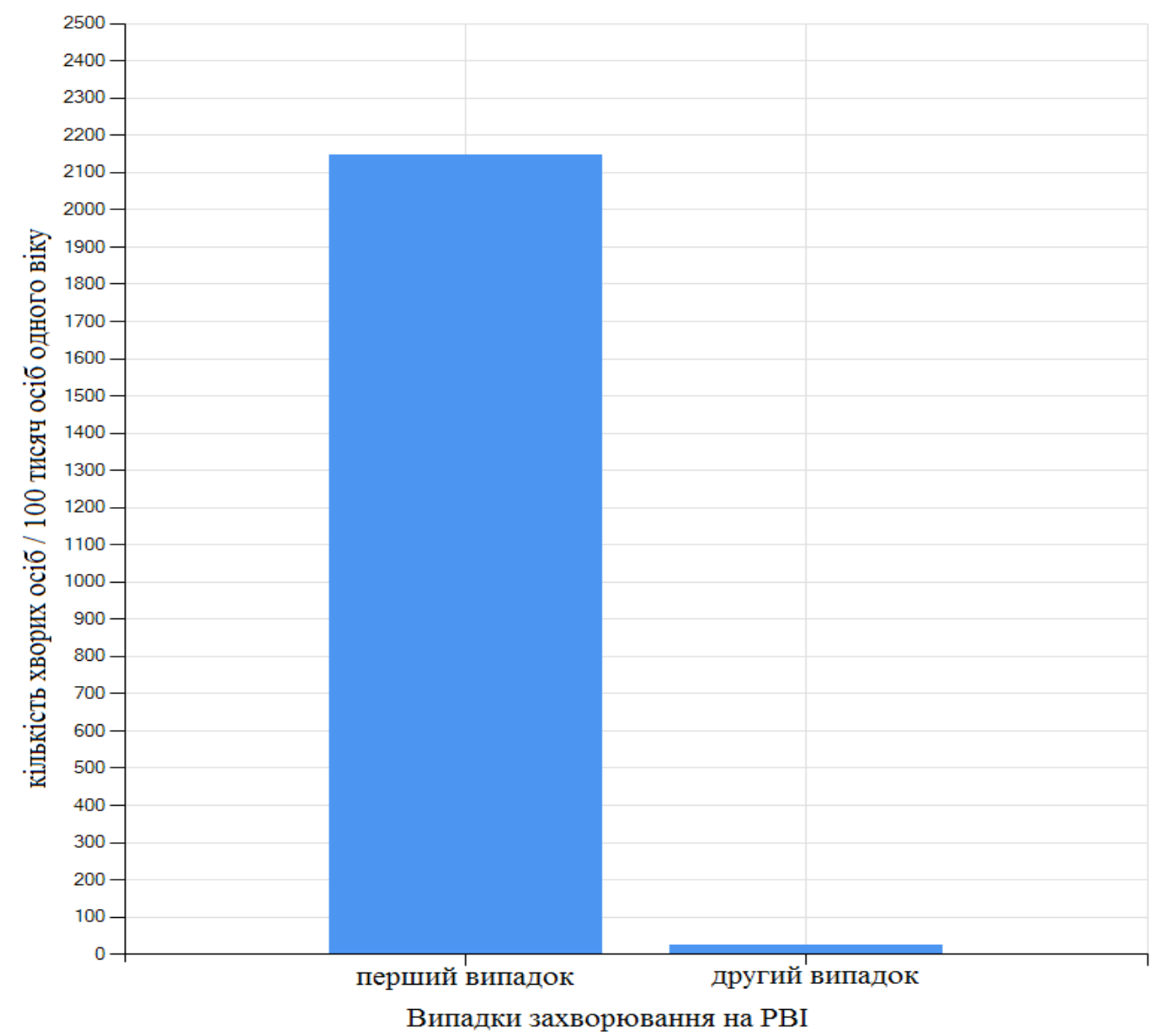

Рис. 4. Очікувана кількість випадків захворювання на РВІ для новонароджених осіб протягом п'яти років життя.

хворювання на РВІ, нашим дослідженням було показано, що кількість первинних випадків захворювання значно домінує над кількістю наступних випадків у структурі захворюваності на РВІ серед дітей віком до п'яти років в Україні. Це має значну вагу при оцінці есрективності та фрармакоекономічному дослідженні специфічної профрілактики РВІ серед дітей України, оскільки мають бути враховані витрати на лікування першого випадку захворювання та можуть бути знехтувані наступні випадки як набагато менш ймовірні.

\section{АНАЛИЗ ПОВТОРНЫХ СЛУЧАЕВ ЗАБОЛЕВАНИЯ В ОЦЕНКЕ СТОИМОСТИ ЗАБОЛЕВАНИЯ РОТАВИРУСНОЙ ИНФЕКЦИЕЙ}

\section{С. А. Соловьев ${ }^{1,2}$, Г. А. Мохорт ${ }^{3}$, М. В. Лелека', Л. А. Курсенко ${ }^{2}$}

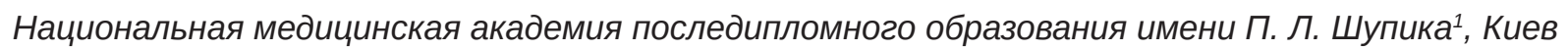
Национальный технический университет Украины «Киевский политехнический институт имени Игоря Сикорского»², Киев

Национальный медицинский университет имени А. А. Богомольца ${ }^{3}$, Киев

solovyov.nmape@gmail.com

Цель работы. Оценка повторных случаев заболевания ротавирусной инфекцией (РВИ) с использованием ретроспективных эпидемиологических данных и методов математического и компьютерного моделирования.

Материалы и методы. Инорормационной основой анализа стали ретроспективные эпидемиологические данные ежемесячной заболеваемости РВИ в Украине с 2010 по 2016 г., методы математического и компьютерного моделирования.

Результаты и обсуждение. С использованием разработанного программного обеспечения были определены вероятность заболевания РВИ для различных возрастных групп и ожидаемое количество первичного и

ISSN 2312-0967. Pharmaceutical review. 2018. № 2 
последующих случаев заболевания для новорожденных детей в течение первых пяти лет жизни. Было определено, что наибольшей является вероятность заболевания РВИ у детей в возрасте от 1 до 2 лет, что согласуется с общемировыми тенденциями. Несмотря на то, что в мире принято считать первые несколько случаев заболевания РВИ, результаты компьютерного моделирования показали, что количество первичных случаев заболевания значительно доминирует над количеством следующих случаев в структуре заболеваемости РВИ среди детей в возрасте до пяти лет в Украине.

Выводы. Полученные результаты моделирования имеют значительный вес при проведении фрармакоэкономического исследования специфической профилактики РВИ среди детей Украины, поскольку показано, что должны быть учтены расходы на лечение первого случая заболевания и могут не браться во внимание последующие случаи заболевания как гораздо менее вероятные.

Ключевые слова: ротавирусная инфекция; повторное заболевание; компьютерное моделирование; вакцинопросилактика.

\title{
ANALYSIS OF SUBSEQUENT DISEASE CASES IN ESTIMATION OF COST OF ILLNESS OF ROTAVIRUS INFECTION
}

\author{
S. O. Soloviovi,2, H. A. Mokhort ${ }^{3}$, M. V. Leleka ${ }^{1}$, L. O. Kursenko ${ }^{2}$ \\ P. Shupyk National Medical Academy of Postgraduate Education ${ }^{1}$, Kyiv \\ National Technical University of Ukraine «Ihor Sikorskyi Kyiv Polytechnic Institute»², Kyiv \\ O. Bohomolets National Medical University ${ }^{3}$, Kyiv \\ solovyov.nmape@gmail.com
}

The aim of the work. Evaluation of subsequent cases of rotavirus infection (RVI) using retrospective epidemiological data and mathematical and computer modeling.

Materials and Methods. The information basis for the analysis was the retrospective epidemiological data of monthly RVI morbidity in Ukraine from 2010 to 2016, methods of mathematical and computer modeling.

Results and Discussion. Using the developed software, probabilities of RVI in different age groups and the expected number of primary and subsequent cases of disease for newborns in the first five years of life were determined. The highest probability of the disease was observed in children in the age of 1-2 years, which is consistent with world trends. Despite the fact that in the world it was decided to take into account the first few cases of RVI, the results of computer simulations showed that the number of primary cases significantly dominates the number of subsequent cases in the morbidity of RVI among children under five years of age in Ukraine.

Conclusions. The obtained modeling results are of great importance when carrying out a pharmacoeconomic study of specific prevention of RVI among children of Ukraine, since it has been shown that the costs of treatment of the first case of illness should be taken into account and subsequent disease cases, as much less likely, can be neglected.

Key words: rotavirus infection; subsequent disease case; computer modeling; vaccination.

\section{Список літератури}

1. Покровский В. И. Инфекционные болезни в эпоху глобализации / В. И. Покровский, Н.И.Брико // Вестник PAMH. - 2010. - № 11. - C. 6 - 11 .

2. Burden of rotavirus gastroenteritis and distribution of rotavirus strains in Asia: a systematic review / K. Kawai, M. A. O'Brien, Goveia [et al.] // Vaccine. - 2012. - Vol. 8; 30 (7). - P. 12441254. doi: 10.1016/j.vaccine.2011.12.092.

3. Umesh D. Parashar Global mortality assotiated with rotavirus disease among children in 2004 / D. Umesh // JID. - 2009. - Vol. 200 (Suppl. 1). - P. 9-15.

4. 2008 estimate of world wide rotavirus-associated mortality in children younger than 5 years before the introduction of universal rotavirus vaccination programmes: a systematic review and meta-analysis / J. E. Tate, A. H. Burton, C. Boschi-Pinto [et al.] // Lancet Infect Dis. - 2012. - Vol. 12(2).

- P. 136 41. doi: 10.1016/S1473-3099(11)70253-5

5. Сергевнин В. И. Острые кишечные инфекции.
Проявления эпидемического процесса / В. И. Сергевнин // Врач. - 2013. - № 9. - С. 18-20.

6. Шилов Г. Ю. Анализ заболеваемости острыми кишечными инфекциями в Российской Федерации, США и странах Евросоюза / Г. Ю. Шилов, Е. А. Смирнова // Пищевая промышленность. - 2013. - № 10. - С. 50-54 7. Еженедельный эпидемиологический бюллетень. 2013. - № 5. - C. 49-64 (http://www.who.int/wer)

8. Миндлина А. Я. Пути оптимизации эпидемиологического надзора за антропонозами с фекальнооральным механизмом передачи / А. Я. Миндилина // Эпидемиология и инорекционные болезни. - 2012. № 4. - C. 16-20.

9. Оценка роли условно-патогенной фрлоры в развитии острых диарейных заболеваний / А. Т. Подколзин, Т. А. Коновалова, И. А. Бочков [и др.] // Инфекционные болезни. - 2012. - Т. 10. - № 3. - С. 53-55.

ISSN 2312-0967. Фармацевтичний часопис. 2018. № 2 
10. Сергевнин В. И. Острые кишечные инфрекции. Проявления эпидемического процесса / В. И. Сергевнин // Врач. - 2013. - № 9. - С. 18-20.

11. Дзюблик І. В. Швидкі тести та їх місце в етіологічній діагностиці гострих кишкових вірусних інсекцій / І. В. Дзюблик, І. Ф. Самборська, С. О. Соловьев // Здоров'я суспільства. - 2013. - № 2. - С. 50-57.

12. Малый В. П. Общая характеристика острых кишечных инорекций / В. П. Малый // Клінічна імунологія. Алергологія. Інфектологія. - 2010. - № 7(36). - С. 14-32. 13. Rotavirus G9P in 3 countries in Latin America, 20092010 / O. Quae, S. McDonald, M. D. Esona [et al.] // Emerg. Infect. Dis. - 2013. Vol. 19 (8). - P. 1332-1333.

14. Setting research priorities to reduce mortality and morbidity of childhood diarrhoeal disease in the next 15 years / Kerri Wazny, Alvin Zipursky, Robert Black [et al.] // PLoS Med. - 2013. - Vol. 10 (5). e1001446 doi: 10.1371/journal.pmed.1001446 15. Rotavirus infections in infants as protection against subsequent infections / F. R. Velazquez, D. O. Matson,
J. J. Calva [et al.] // N. Engl. J. Med. 1996. - Vol. 335. P. 10221028.

16. Protective effect of natural rotavirus infection in an Indian birth cohort / B. P. Gladstone, S. Ramani, I. Mukhopadhya [et al.] // N. Engl. J. Med. 2011. - Vol. 365. P. 337-346.

17. Соловйов С. О. Деякі підходи до моделювання повторних випадків захворювання на ротавірусну інсекцію серед дітей України / С. О. Соловйов, І.В.Дзюблик // Збірник наукових праць співробітників НМАПО ім. П. Л Шупика. 2013. - Вип. 22(4). - С. 506-515.

18. Martsenyuk VP, Ghyipa NV, Kashuba MO. [Information and statistical approach to the modeling of the spread of infectious disease on the example of the epidemic of ARI during the period of October-November 2009 in the Ternopil region]. Infectious diseases. 2013;4:50-9. Ukrainian

19. Briggs A. An introduction to Markov modelling for economic evaluation / A. Briggs, M. Sculpher // Pharmacoeconomics. - 1998. - Vol. 13 (4). - P. 397409.

\section{References}

1. Pokrovsky VI, Bricco NI. [Infectious diseases in the age of globalization] Vestnik RAMN. 2010;1:6- 11. Russian.

2. Kosuke Kawai, Megan A. O'Brienb, Michelle G. Goveia, T. Christopher Mast, Antoine C. El Khoury. The burden of rotavirus gastroenteritis and the distribution of rotavirus strains in Asia: a systematic review. Vaccine. 2012;(7): 124454. Available from: [doi: 10.1016 / j.vaccine.2011.12.092.]

3. Umesh D. Parashar Global mortality assotiated with rotavirus disease among children in 2004. JID. 2009;200(1): 9-15.

4. Jacqueline E Tate, Anthony $\mathrm{H}$ Burton, Cynthia BoschiPinto, A Duncan Steele, Jazmin Duque, Umesh D Parashar. 2008 estimate of global rotavirus-associated mortality in children younger than 5 years before the introduction of universal rotavirus vaccination programs: a systematic review and meta-analysis. Lancet Infect Dis Feb. 2012;12(2): 136-41. Available from: [doi: 10.1016 / S1473-3099 (11) 70253-5]

5. Sergeevnin VI [Acute intestinal infections. Manifestations of the epidemic process]. Vrach. 2013;9: 18-20. Russian.

6. Shilov G.Yu. [Analysis of the incidence of acute intestinal infections in the Russian Federation, the United States and EU countries] Pishchevaya promyshlenost. 2013;10: 50-4. Russian.

7. Weekly epidemiological bulletin. 2013;5: 49-64. - Available from: http://www.who.int/wer.

8. Mindlina AYa. [Ways of optimization of epidemiological surveillance for anthroponoses with fecal-oral transmission mechanism]. Epidemiologiya i infektsionnye bolezni. 2012;4: 16-20. Russian.

9. Podkolzin AT, Konovalova TA, Bochkov IA, Lavreonova ES. [Estimation of the role of conditionally pathogenic flora in the development of acute diarrheal diseases] Infektsyonnye bolezni. 2012;10: 53-5. Russian.

10. Sergeevnin V.I. [Acute intestinal infections. Manifestations of the epidemic process / VI Sergeevnin]. Vrach. 2013;9: 18-20. Russian.
11. Dzyublyk IV, Samborskaya IF, Solovyov SO. [Fast tests and their place in the etiological diagnosis of acute intestinal viral infections]. Zdorovya suspilstva. 2013;2: 50-7. Ukrainian. 12. Maluy VP. [General characteristics of acute intestinal infections] Klin imunolohiia. Allerholohiia. Infektolohiia. 2010;7(36): 14-32. Russian.

13. Osbourne Quaye, Sharla McDonald, Mathew D. Esona, Freda C. Lyde, Slavica Mijatovic-Rustempasic, Sunando Roy et al. Rotavirus G9P[4] in 3 countries in Latin America, 2009-2010. Emerg. Infect. Dis. 2013;19(8): 1332-33.

14. Kerri Wazny, Alvin Zipursky, Robert Black, Valerie Curtis, Christopher Duggan, Richard Guerrant et al. Setting research priorities to reduce mortality and morbidity of childhood diarrhea disease in the next 15 Years. PLoS Med. 2013;10(5): e1001446. Available from: [doi: 10.1371 / journal.pmed.1001446]

15. Velázquez FR, Matson DO, Calva JJ, Guerrero L, Morrow AL, Carter-Campbell S. et al Rotavirus infections in infants as protection against subsequent infections. N Engl J Med.1996;335: 1022-28.

16. Gladstone BP, Ramani S, Mukhopadhya I, Muliyil J, Sarkar R, Rehman AM, et al. Protective effect of natural rotavirus infection in an Indian birth cohort. $\mathrm{N}$ Engl J Med. 2011;365: 337-46.

17. Solovyov SO, Dzyublyk IV. [Some approaches to the modeling of repeated cases of rotavirus infection among children of Ukraine]. Collection of scientific works of NMAPE employees. P. L. Shupyka. 2013;22(4): 506-15. Ukrainian. 18. Martsenyuk VP, Ghyipa NV, Kashuba MO. [Information and statistical approach to the modeling of the spread of infectious disease on the example of the epidemic of ARI during the period of October-November 2009 in the Ternopil region]. Infectious diseases. 2013;4:50-9. Ukrainian 19. Briggs A, Sculpher M. An introduction to Markov modelling for economic evaluation. Pharmacoeconomics. 1998;13(4): 397-409. 